\title{
Implementasi Corporate Social Responsibility pada Hotel Puri Santrian Sanur Bali
}

\author{
Ni Made Yuni Sri Nadiawati ${ }^{1}$ \\ Fakultas Ekonomi dan Bisnis \\ Universitas Udayana, Indonesia
}

\author{
I G.A.N. Budiasih ${ }^{2}$ \\ Fakultas Ekonomi dan Bisnis \\ Universitas Udayana, Indonesia
}

Surel : nimadeyunisrinadiawati@gmail.com

\begin{abstract}
ABSTRAK
Penerapan CSR dianggap memberikan keuntungan bagi industri perhotelan, sehingga akan berdampak pada meningkatnya loyalitas pengunjung. Salah satu penghargaan CSR di Bali adalah Tri Hita Karana (THK Award). Puri Santrian salah satu hotel yang turut serta menjadi peserta dalam Tri Hita Karana Award. Tujuan Penelitian ini adalah untuk mengetahui implementasi CSR pada hotel Puri Santrian. Metode penelitian ini menggunakan metode kualitatif. Lokasi penelitian ini adalah Hotel Puri Santrian. Informan yang dipilih adalah staf HRD, Staf Engineering, Staf Accounting. Hasil wawancara menunjukkan Puri Santrian telah melaksanakan CSR berlandaskan filosofi Tri Hita Karana dengan baik. Namun, Pada bagian pawongan bantuan yang diberikan dapat lebih bervariasi.
\end{abstract}

Kata Kunci: Corporate Social Responsibility; Tri Hita Karana; Implementasi Praktik CSR.

\section{Corporate Social Responsibility Implementation At Puri Santrian Hotel Sanur Bali}

\section{ABSTRACT}

The implementation of CSR is considered to benefit the hospitality industry, which will impact on increasing visitor loyalty. One of the CSR awards in Bali is Tri Hita Karana (THK Award). Puri Santrian, one of the participating hotels, is a participant in the Tri Hita Karana Award. The purpose of this research is to know the implementation of CSR in Puri Santrian Hotel. This method of research uses qualitative methods. The location of this research is Hotel Puri Santrian. The informant chosen is HRD staff, Engineering staff, Accounting staff. The interview shows the Santrian Palace has implemented CSR based on the well-established philosophy of Tri Hita Karana. However, in the part of the given assistance can be more varied.

Keywords: Corporate Social Responsibility, Tri Hita Karana, Implementation Of CSR Practices.

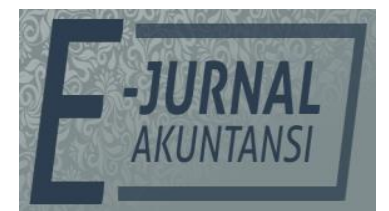

e-ISSN 2302-8556

Vol. 31 No. 2

Denpasar, Februari 2021

Hal. 451-462

DOI:

10.24843/EJA.2021.v31.i02.p15

PENGUTIPAN:

Nadiawati, N.M.Y.S., \&

Budiasih, I G.A.N. (2021).

Implementasi Corporate Social Responsibility pada Hotel Puri Santrian Sanur Bali. E-Jurnal Akuntansi, 31(2), 451-462

RIWAYAT ARTIKEL: Artikel Masuk: 28 Juni 2020 Artikel Diterima: 12 Juli 2020

Artikel dapat diakses : https://ojs.unud.ac.id/index.php/Akuntansi/index 


\section{PENDAHULUAN}

Bali mempunyai salah satu budaya masyarakat yang masih kental dengan nilai religiusnya. Kehidupan sosial budaya di Bali berlandaskan ajaran agama Hindu yang merupakan agama mayoritas di Bali sehingga masyarakat Bali harus menjaga nilai-nilai kearifan lokal yang mereka miliki. Pelaksanaan praktik CSR yang selama ini dilaksanakan berdasarkan teori-teori tersebut belumlah mampu mengintegrasikan penerapan CSR dengan nilai kearifan lokal maupun adat istiadat di Bali. Salah satu filosofi yang dapat menjadi dasar pelaksanaan praktik CSR guna menciptakan keharmonisan dalam menjalin hubungan sebagai manusia yaitu ajaran Tri Hita Karana. Di Pulau Bali nilai filosofis yang dikenal dengan sebutan Tri Hita Karana yang memiliki arti pola keselarasan untuk mencapai keharmonisan dalam menjalankan segala aktivitas di kehidupan sehari-hari. Konsep CSR dapat berjalan seirama dengan unsur-unsur yang terkandung dalam Tri Hita Karana. Penyelarasan dan pengidentifikasian Program CSR dengan Konsep Tri Hita Karana yang merupakan salah satu nilai kearifan lokal di Bali yang diharapkan mampu memberikan suatu akar pondasi yang kuat untuk membentuk suatu kerjasama dengan publik atau masyarakat yang lebih baik kedepannya. Pengidentifikasian penerapan CSR berbasis Tri Hita Karana penting dilakukan dikarenakan sebuah nilai filosofis suatu budaya bukan menjadi hal yang harus di manifestasikan nilai-nilainya. Sehingga, dalam membentuk kerjasama yang baik diperlukan adanya peran seluruh manajemen yang mendukung dan mengkomunikasikan program CSR agar selaras dengan Tri Hita Karana. Salah satu hotel di Sanur yang turut serta menjadi peserta dalam Tri Hita Karana Award dan berhasil mendapatkan THK Awards beberapa kali adalah Santrian Groups. Pada tahun 2014 Santrian Groups berhasil menerima 3 Awards dari ajang Tri Hita Karana Awards yakni, 1 Platinum Medal dan 2 Emerald Medal. Keberhasilan Santrian Groups dalam mengimplementasikan CSR perlu ditiru hotel-hotel lain di Bali khususnya hotel-hotel yang belum menerapkan CSR dengan serius.

Penerapan CSR tentu saja memberikan dampak bagi perusahaan yang menjalankannya. Banyak jurnal-jurnal penelitian yang membeberkan bawasannya CSR memberikan dampak yang baik bagi keuangan perusahaan. Suciawati, (2016) dalam jurnalnya mendapatkan hasil bahwa pengungkapan CSR berpengaruh signifikan positif terhadap ROA dan ROE. Hal ini juga diungkapkan dengan penelitian ilmiah K. C. Sari, (2018) menyatakan bahwa Corporate Social Responsibility (CSR) berpengaruh signifikan terhadap Return On Assets (ROA), Corporate Social Responsibility (CSR) berpengaruh signifikan terhadap Return On Equity (ROE), Corporate Social Responsibility (CSR) berpengaruh signifikan terhadap Earning per Share (EPS). Kemudian Pramana \& Yadnyana, (2016) mengungkapkan bahwa CSR berpengaruh signifikan pada kinerja keuangan perusahaan dan CSR berpengaruh signifikan kinerja pasar perusahaan Namun, tidak sedikit pula penelitian yang justru kontra dengan pernyataan tersebut, misalnya penelitian yang dilakukan Bangun et al., (2019) menungkapkan pengungkapan corporate social responsibility tidak memiliki pengaruh signifikan untuk memproyeksikan kinerja keuangan perusahaan.

Dari beberapa penelitian dengan metode kuantitatif peneliti berusaha mengungkapakan implementasi CSR di perusahaan dan dampak yang diberikan 
bagi perusahaan setelah menerapkan CSR. Peneliti berusaha mengkaji lebih dalam penerapan CSR melalui wawancara mendalam dengan tokoh penting dalam penerapan CSR di perusahaan, yang dalam penelitian ini perusahaan yang dipilih adalah Hotel Puri Santrian. Penelitian ini menggunakan metode kualitatif untuk mengetahui bahwa implementasi CSR telah dilakukan di perusahaan dengan baik dan sesuai dengan aturan dan filosofi kebudayaan lokal yang ada dan bukan formalitas semata. Adapun penelitian sebelumnya menggunakan metode kualitatif yakni Rosilawati dan Mulawarman, 2019 dengan judul Kearifan Lokal Tri Hita Karana Dalam Program Corporate Social Responsibility yang mengungkapkan bahwa CSR yang dilaksanakan oleh Aqua Danone Bali memiliki perspektif Sustainable Development sesuai dengan kerangka WBCSD (2002) yang bertujuan untuk meningkatkan kualitas kehidupan masyarakat. Adapun penelitian lainnya Pertiwi dan Ludigdo, 2019 dengan penelitian Implementasi Corporate Social Responsibility Berlandaskan Budaya Tri Hita Karana, yang mengungkapkan bahwa penerapam implementasi CSR dengan budaya THK di Discovery commu- nity Kartika Plaza Hotel sangat baik dan sudah sesuai dengan tradisi budaya maupun aturan CSR yang berlaku. Dengan acuan dua penelitian tersebut, peneliti melakukan penlitian dengan menambahkan aspek dampak penerapan CSR pada aspek Triple Bottom Line.

\section{METODE PENELITIAN}

Metode penelitian dalam penelitian ini menggunakan menggunakan metode penelitian kualitatif. penelitian kualitatif didefinisikan sebagai penelitian yang bermaksud untuk memahami fenomena tentang apa yang dialami oleh subjek penelitian, misalnya perilaku, persepsi, motivasi, tindakan, dll. Lokasi penelitian yang dipilih pada penelitian ini adalah Puri Santrian Hotel. Puri Santrian Hotel merupakan salah satu hotel bintang empat yang terletak di kawasan Pantai Sindhu, Sanur, Bali. Lokasi ini dipilih karena Puri Santrian bernaung di bawah Santrian Groups yang menuntut tiap hotelnya melakukan CSR dengan baik. Santrian Groups rutin menjadi peserta THK Awards setiap tahun, bahkan beberapa kali mendapatkan THK Awards serta Bali Tourism Award 2017 yang merupakan ajang bergengsi bagi Industri hotel di Bali.

Sugiyono, ( 2017:449) menyatakan bahwa informan sebagai sumber data memenuhi kriteria sebagai berikut: (1) Mereka yang menguasai atau memahami sesuatu melalui proses enkulturasi sehingga situasi itu bukan sekedar diketahui, tetapi juga dihayatinya. (2) Mereka yang tergolong masih sedang berkecimpung atau terlibat pada kegiatan yang tengah diteliti. (3) Mereka yang memunyai waktu yang memadai untuk dimintai informasi. (4) Mereka yang tidak cenderung menyampaikan informasi hasil "kemasannya" sendiri. (5) Mereka yang pada mulanya tergolong cukup asing dengan peneliti sehingga lebih menggairahkan untuk dijadikan semacam guru atau narasumber.Pada penelitian ini informan yang dipilih ialah Staf Human Resource Development, , Staf Accounting, dan Staf Engineering dari Puri Santrian Hotel. Ketiga informan tersebut akan memberikan informasi mengenai pelaksanaan praktik CSR di Puri Santrian Hotel melalui teknik wawancara secara mendalam. Objek yang dijadikan sumber dalam penelitian ini adalah CSR Puri Santrian. Metode pengumpulan data yang digunakan dalam penelitian ini adalah diperoleh 
wawancara. Teknik keabsahan data dalam penelitian ini adalah teknik triangulasi dan member checking.

\section{HASIL DAN PEMBAHASAN}

Pelakasanaan CSR pada Puri Santrian cukup terstruktur, meskipun masih belum bisa dikatakan sempurna. Dalam pelaksanaan CSR pihak pihak terkait akan mendapatkan arahan dari GM atau General Manager, kemudian pihak HR Secretary akan menyerahkan usulan terkait CSR yang akan disetujui oleh GM. Selain dari pihak HRD, pelaksanaan CSR juga dilakukan atas dasar usulan owner atapun GM. Dalam pelaksaan CSR staf Puri Santrian dibagi menjadi tiga bagian, yakni bagian pawongan yang dilaksanakan oleh bagian HR Manager, bagian pelemahan yang dilaksanakan oleh bagian engineering dan executive housekeeper, dan bagian parahyangan dilaksanakan oleh HR Officer. Setelah pelaksanaan CSR dilakukan oleh staf Puri Santrian, masing masing bagian pelaksanaan CSR harus melaporkan hasil kegiatan terhadap HR Secretary yang kemudian mengumpulkan segala pelaksanaan CSR di Puri Santrian sebagai bukti pada saat mengikuti ajang Tri Hita Karana Award.

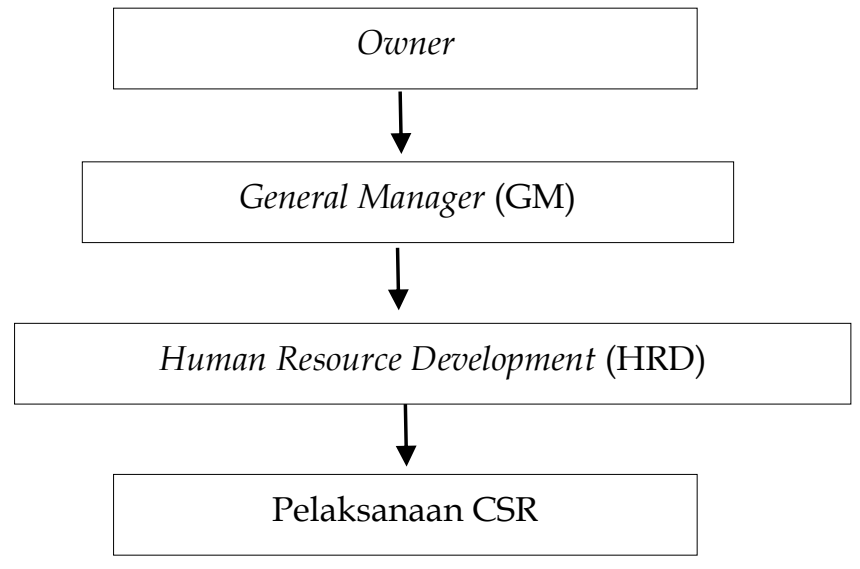

\section{Gambar 1. Struktur Pelaksanaan CSR}

Sumber: Human Resource Development Puri Santrian, 2020

Implementasi atas pelaksanaan praktik CSR perusahaan di bidang ketuhanan telah dilakukan di internal maupun di eksternal perusahaan. Ini diketahui dari hasil wawancara dengan Informan HR Secretary Putu Monik Deviana Sari ketika disinggung mengenai adanya kegiatan keagamaan di hotel Puri Santrian "Pasti, apalagi mayoritas karyawan dan pemilik beragama hindu, saat rahinan itu biasanya akan dilakukan persembahyangan bersama, bagi umat muslim biasanya juga mengadakan acara bukber bersama, mungkin bisa dibilang ini wujud toleransi antar agama".

Dari hasil wawncara di Internal Puri Santrian praktik parahyangan (bentuk rasa syukur terhadap tuhan yang maha esa) dapat dilihat didrikannya Pura di sekitar hotel Puri Santrian yang terdiri atas pelinggih padma, tugu, penunggun karang . Kemudian pada saat hari suci agama Hindu, karyawan secara bersamasama melakukan persembahyangan, tidak hanya bagi umat hindu hari raya bagi umat lain pun turut dirayakan, seperti pada saat bulan puasa bagi umat muslim, karyawan melakukan buka puasa bersama. Hal ini menunjukkan rasa toleransi 
yang tinggi antar umat beragama di Puri Santrian, serta rasa syukur terhadap Tuhan Maha Esa. Selain merayakan hari raya bagi karyawan, Puri Santrian juga akan turut merayakan natal dan tahun baru bagi para wisatawan yang berkuunjung, utamanya wisatawan mancanegara yang mayoritas beragama kristen. Perayaan ini dilakukan dengan cara menghias hotel dengan pohon natal dan adanya karyawan yang menggunakan pakaian santaclause. Dari hasil wawancara bersama informan, didapatkan fakta bahwa selain di Internal pelaksanaan bidang ketuhanan juga dilakukan di eksternal Puri Santrian "Kontribusi kita dengan pura disekitar hotel, kita wujudkan dengan memberikan sumbangan, dalam istilah bali dana punia, beberapa kali kita juga turut ngayah di Pura ".

Kegiatan bidang ketuhanan secara eksternal dari Puri Santrian diwujudkan dengan turut serta berpartispasi dalam kegiatan-kegiatan keagamaan melalui dana punia yakni sumbangan sukarela dalam bentuk apapun dengan keikhlasan dan ngayah yang merupakan tradisi adat Bali yang secara gotong royong mempersiapkan dan melaksanakan upacara keagamaan. Ini penting dilakukan untuk menunjukkan rasa syukur Puri Santria kepada Tuhan Yang Maha Esa dan masyarakat sekitar. Hal ini menunjukkan bahwa Puri Santrian turut serta dalam kegiatan-kegiatan beragama di lingkungan sekitar khususnya Sanur dan ikut menjaga buday dan tradisi leluhur di pulau Bali.

Pelaksanaan praktik CSR di perusahaan dilakukan oleh pihak Puri Santrian sama halnya seperti bidang ketuhanan, Puri Santrian juga telah melaksanakan kewajibannya menolong dan menghargai manusia di perusahaan yakni karyawan dan pengunjung/tamu. Pelaksaan CSR di perusahaan dilakukan dengan baik dan selaras oleh Puri Santrian. Puri Santrian berusaha sebaik mungkin menjaga hubungan dengan karyawan ini dapat diketahui dari hasil wawancara dengan informan Putu Monik Deviana Sari. “Gaji sudah sesuai dengan UMK kabupaten beserta dengan tunjangan kesehatan, Hotel kami mengacu kepada Peraturan Pemerintah mengenai ketenaga kerjaan. Hotel mengikut sertakan seluruh karyawan dalam Program BPJS Kesehatan"

Gaji yang sesuai dan tunjangan kesehatan merupakan dua hal terpenting bagi karyawan di setiap perusahaan. Dengan memberikan gaji sesuai UMK Denpasar, dan tunjangan kesehatan, karyawan tentu saja merasa tenang dan senang bekerja di Puri Santrian. Selain itu Puri Santrian juga turut merayakan ulang tahun karyawan, meskipun hanya dilakukan dengan cara memberikan kue dan peniupan lilin, hal ini tentu saja memberikan kebahagiaan tersendiri bagi karyawan.

Tahun 2019 hanya terdapat 3 karyawan yang mengundurkan diri dari Puri Santrian, yang disebabkan mendapatkan jabatan yang lebih tinggi. Tidak hanya itu, Puri Santrian juga memberikan pelatihan bagi tiap bidang yang ada di Puri Santrian "Karyawan mendapatkan pendidikan dan pelatihan sesuai bidangnya, karena kita mempunyai Learning Manager dan dilaksanakan berkala sesuai jadwal yang sudah ditentukan, karyawan juga dipilih melalui proses training, kita selalu melaksanakan interview sebelum memilih kandidat yang tepat". 
Dari hasi wawancara dapat diketahui Puri Santrian begitu selektif dalam memilih rekan atau mitra kerja. Puri Santrian juga terus mengasah dan meningkatkan kemampuan karyawan demi dapat menyajikan pelayanan yang terbaik bagi pengunjung, sehingga pengunjung merasa nyaman dan senang. Pengunjung atau wisatawan juga diberikan pertanyaan-pertanyaan untuk menunjukkan tingkat kepuasaan pelanggan dengan pelayanan karyawan Puri Santrian, pengunjung berhak memberikan kritik ataupun saran demi meningkatkan kualitas pelayanan Puri Santrian. "Iya kami melakukan survey tersebut dengan menyebar guest comment di masing-masing room, rest dan juga di FO".

Untuk masyarakat sekitar, Puri Santrian menghargai masyarakat sekitar khususnya Sanur dengan cara menyerap tenaga kerja lokal. Puri Santrian juga semaksimal mungkin menggunakan produk asli bali, hal ini diakui oleh Informan pada saat melakukan wawancara "sebagian besar karyawan orang Lokal (Bali), Dari total karyawan 509 orang terdapat 25 orang Muslim, 4 orang Christian, 480 orang Hindu dan tidak ada WNA, untuk produk Hotel Puri Santrian selalu mengutamakan hasil bumi dan produksi dari masyarakat lokal Pembelian sayur mayur dari pedagang Bedugul, Sanur, Badung."

Puri Santrian berkomitmen untuk semaksimal mungkin menggunakan produk hasil bumi dan produksi dari masyarakat lokal. Ini membuktikan bahwa Puri Santrian bersungguh-sungguh untuk ikut serta meningkatkan kesejahteraan masyarakat bali khususnya lingkungan Sanur. Selain menghargai warga sekitar, Puri Santrian turut membantu masyarakat luas dengan program-program CSR . "Banyak sekali program CSR yang kami lakukan diantaranya kami melakukan donor darah, kemudian memberikan suumbangan bagi adik-adik panti asuhan dan Bedah Rumah di Bangli, kemudian membantu korban longsor songan kalau tidak salah tahun 2017, dan sumbangan yang diperuntunkan bagi pura-pura yang berada di sekitar hotel, serta sumbangan bagi korban gempa lombok".

Rasa kemanusiaan yang tinggi ditunjukkaan oleh pihak Puri santrian melaui acara -acara amal yang dilakukan. Pada hari Ulang Tahun Puri Santrian dipilih sebagai hari untuk melaksanakan kegiatan bidang kemanusiaan ini. Hari Ulang tahun ini dipilih sebagai rasa syukur Puri Santrian untuk tetap dapat bertahan sebagai salah satu Hotel pilihan wisatawan. Rangkaian kegiatan CSR bidang kemanusiaan Puri Santrian dimulai pada tanggal 22 April 2019 puri santrian mengunjungi masyarakat kurang mampu di kabupaten Bangli dan memberikan santunan berupa uang tunai, sembako serta kebutuhan sehari-hari lainnya yang bermanfaat bagi masyarakat. Kemudian dilanjutkan dengan kegiatan berikutnya pada tanggal 23 April 2019 dengan mengunjungi Panti Asuhan dan memberikan bantuan berupa uang tunai, sembako dan alat-alat tulis. Pada puncak hari ulang tahun Puri santrian yakni 24 April 2019, Puri Santrian melakukan kegiata donor darah yang diikuti oleh karyawan dan pemiliki Puri Santrian, yang bertempat di Hotel Puri Santrian. Tidak hanya bagi warga Bali, Puri Santrian juga menunjukkan rasa simpatinya bagi korban bencana gempa Lombok. Banyaknya uluran tangan Puri Santrian bagi mereka yang membutuhkan tentu saja perlu diapresiasi, perbuatan baik yang dilakukan dengan tulus dan ikhlas pasti akan membuahkan hasil yang baik pula. 
Implementasi praktik CSR dilingkungan telah dilakukan di internal dan eksternal perusahaan. Adapun implementasi praktik CSR di lingkungan internal Puri Santrian yakni dengan menggunakan bahan-bahan ramah lingkungan seperti chemical atau zat kimia yang digunakan adalah chemical yang ramah lingkungan. Kemudian mengganti straw berbahan plastik dengan straw berbahan dasar kulit jagung, hal ini tentu saja perlu di apresiasi mengingat kulit jagung juga sangat mudah ditemukan di Bali. Tidak hanya mengganti straw berbahan dasar plastik, Puri Santrian juga menunjukkan pengimplementasian CSR dilingkungan internal dengan mengganti plastik menjadi box atau kardus dan kertas sebagai pengganti tas plastik, Puri Santrian juga menggunakan kayu dalam menghias panggung. Pemilahan sampah organik dan anorganik juga dilakukan oleh pihak Puri Santrian. Mengolah sampah anorganik dengan $3 \mathrm{R}$ atau Reuse, Reduce, dan Recycle sampai sekarang masih menjadi cara terbaik dalam mengelola dan menangani sampah dengan berbagai permasalahannya. Hal ini diurakan berdasarkan hasil wawancara dengan HR Secretary."Kami semaksimal mungkin menggunakan bahan-bahan yang ramah lingkungan, seperti Chemical yang dimanfaatkan adalah chemical yang ramah lingkungan, Straw yang kita gunakan dari Kulit Jagung, Box untuk take away, pizza dan tas kita menggunakan kertas, Hiasan untuk panggung yang biasanya menggunakan sterofoam diganti menggunakan kayu. Kami juga ada pemisahan sampah organik dan anorganik. Yang anorganik dipisah lagi berupa kaleng/kemasan, kertas, botol dan plastik untuk di-reuse, recycle, recovery. Yang organik sebagian dimanfaatkan".

Untuk bagian limbah B3 yakni limbah dengan bahan berbahaya dan beracun pihak Puri Santrian mengeluarkan biaya 475 ribu pertangki. Puri Santrian memilih menggunakan jasa pengolahan limbah yang berada di daerah Sesetan, Denpasar. Hal ini diketahui dari hasil wawancara bersama informan Made Mardiawan (Engineering). “Untuk masalah limbah, kita memanggil pihak luar yang di Sesetan jasa kurasamba, pertangki biasanya kita kenak biaya 475 ribu rupiah".

Selain menjelaskan mengenai pengelolaan limbah B 3, Bli Made juga menjelaskan mengenai penggunaan energi dan air di hotel Puri Santrian. "Sumber air Puri Santrian ini berasal dari ABT atau Air Bawa Tanah, itu akan diregenerasi oleh softener lagi yang ada di depan yakni watersoftener kemudian akan disalurkan ke gronteng induk, kemudian akan disalurkan ke masingmasing kamar, kalau untuk saving energi, kita hanya menggunakan program mematikan energi yang tidak terpakai misalnya mematikan lampu atau AC saat kamar kosong, itu saja sih yang kita lakukan".

Dalam memanfaatkan ABT hotel perlu digunakan dengan bijak, agar ABT tetap tersedia Puri Santrian membatasi penggunaan air 650 liter per orang, hal ini tentu saja dapat menjaga ketersediaan ABT. Begitu pula dengan penggunaan energi lainnya seperti listrik, menurut hasil wawancara dengan informan, Puri Santrian melakukan saving energi dengan mematikan energi yang tidak dibutuhkan. Selain dari internal Puri santrian, CSR bidang palemahan juga dilakukan di eksternal Puri Santrian. Hal ini diketahui melalui haisl wawancara dengan pihak HR Secretary. "kami melakukan penanaman dan pemeliharaan pohon-pohon termasuk tanaman langka, penebangan pohon pun kami lakukan 
hanya untuk menghindari roboh dan membahayakan lingkungan, kami juga melaukan beach clean up sebagai upaya menjaga kelesatarian pantai yang kami lakukan setiap sabtu"

Puri Santrian mempunyai kegiatan rutin dalam menjaga lingkungan pantai yakni dengan melakukan beach clean up yang dilakukan setiap hari Sabtu. Kegiatan ini diikuti oleh semua staff dan karyawan yang sedang tidak bertugas. Puri Santrian juga ikut menjaga terumbu karang serta melestarikan terumbu karang, para turis dan wiasatawan lokal diikutsertakan dalam kegiatan ini. Wisatawan dapat menikmati indahnya pemandangan bawah laut sekaligus ikut melestarikan dan merawat terumbu karang dengan cara mentransplantasi terumbu karang. Selain untuk ikut serta merawat dan menjaga lingkungan, kegiatan transplantasi ini juga menarik wisatawan untuk ikut terjun langsung mentransplantaskan terumbu karang. Selain melakukan penanaman terumbu karang wisatawan juga turut serta berpartisipasi dalam pembersihan terumbu karang dari algae dan ikan ikan pemakan terumbu karang. Penanaman terumbu karang ini biasanya dilakukan di pagi hari. Selain ikut menjaga kelestarian pantai Lebih dan terumbu karang, Puri santrian juga ikut menjaga kelestarian lama dengan ikut menanam tanaman dan pohon pohon yang terbilang langka . Pohon atau tanaman tersebut diantaranya pohon Jati Belanda, pohon Mangga, Pohon Maja, pohon Bekul, dan jenis pohon atau tanaman lainnya. Puri Santrian juga kerap ikut serta bergotong royong dengan warga sanur untuk menajaga kebersihan wilayah seputaran Hotel.

Banyak penelitian yang menyatakan bahwa dampak CSR bagi perusahaan belum dapat dipastikan memberikan peningkatan kinerja keuangan. Dalam penerapan CSR diperlukan dana yang tidak sedikit, begitu pula dengan dana yang dikeluarkan Puri Santrian dalam menerapkan kegiatan CSR, hal ini diketahui dari hasil wawancara yang dilakukan dengan Bapak Ketut Mariasa. "Kalau dalam setahun, mungkin 50 jutaan itu ada" Pak Mariasa juga menjelaskan sumber pendanaan CSR Puri Santrian " Untuk dananya di dapat dari tamu, keuntungan dari hasil pendapatan".

Dana yang dikeluarkan Puri Santrian dalam melakukan kegiatan CSR sekitar 50 juta rupiah. Dana tersebut didapatkan dari laba penjualan jasa kamar hotel, restauran, spa dan pendapatan lainnya. Ketika disinggung mengenai dampak penerapan CSR bagi keuntungan Puri Santrian, Pak Mariasa memberikan jawabannya "Kalau memberikan dampak yang secara langsung mungkin iya, karena saya juga tidak berkecimpung secara langsung di CSR nya, tapi juga tidak mengganggu keuangan sama sekali, karena kalau kita rugi kan perusahaannya bangkrut. Gini karena kalau dari kita (accounting) kan yang dipengang itu Profit Oriented, kenapa ? karena saya bertanggung jawab kepada perusahaan, Kalau masalah sosial atau CSR itu pihak HRD yang lebih ditekankan, kalau dari peningkatan penjualan kamar mungkin iya tapi tidak signifikan, tetapi keuntungan dari penerapan CSR itu loyalitas dari pengunjung itu terjaga".

Penerapan CSR juga tidak mengganggu keuangan Puri Santrian. Pak Mariasa juga menyatakan bahwa bagian accounting sediri memegang prinsip Profit Oriented, yakni prinsip yang bertujuan mengambil keuntungan sebanyakbanyaknya dari penjualan. Hal ini dilakukan demi menghindari kebangkrutan 
perusahan atau hotel Puri Santrian. Pak Mariasa juga menekankan bahwa tanggung jawab sosial atau CSR di Puri Santrian terletak pada pihak atau staff HRD. Sehingga dari aspek keuntungan dalam hal keuangan belum sepenuhnya dirasakan pihak accounttting Puri Santrian.

Selain berdampak pada keuntungan atau keuangan perusahaan, CSR tentu saja memiliki dampak pada masyarakat di sekitar Puri Santrian maupun masyarakat yang diberikan dana sosial maupun bantuan lainnya. Dalam wawancara bersama bapak Mariasa beliau memberikan opininya mengenai dampak CSR bagi masyarakat. "Kalau dampaknya bagi masyarakat mungkin kesejahteraan masyarakat yang kita bantu meningkat kemudian kepercayaan masyarakat ke Puri Santrian juga meningkat ya, masyarakat tidak merasa dirugikan dari adanya Puri Santrian apalagi sebagian besar karyawan kan berasal dari warga sekitar juga."

Dari jawaban pak Mariasa peneliti dapat mengetahui bahwa dampak penerepan CSR yag dilakukan Puri Santrian terhadap masyarakat cukup besar. Dengan melaksanakan CSR, masyarakat tentu menjadi lebih percaya terhadap Puri Santrian bawasannya Puri Santrian juga memperhatikan masyarakat sehingga tercipta simbiosis mutualisme antara masyarakat dan Puri Santrian. Masyarakat yang mendapatkan bantuan berupa dana maupun bedah rumah dari Puri Santrian tentu saja merasa sangat terbantu, hal ini tentu berpengaruh bagi kualitas hidup mereka dan kesejahteraaan ekonomi mereka pun ikut terbantu.

Adapun hasil wawancara yang peneliti lakukan bersama informan pak Mariasa sebagai berikut, "Ke lingkungan bisa kita liat dari terjaganya lingkungan Puri Santrian, kalau lingkungan bersih dan lestari pasti karyawan dan tamu merasa nyaman, dengan penerapan saving energi kan mengurangi beban juga, kedepan juga untuk generasi selanjutnya bisa merasakan dampaknya".

Seperti yang diungkapkan informan, dampak penerapan CSR bagi lingkungan tidak hanya berdampak pada lingkungan saja. Karyawan, masyarakat, serta wisatawan tentu saja merasakan dampaknya. Lingkungan yang bersih tentu membawa ketenangan dan kenyamanan bagi orang orang disekitar. Manusia dan lingkungan memang erat kaitannya, tanpa lingkungan yang sehat manusia tidak akan dapat merasakan ketenangan. Dengan melakukan CSR Puri Santrian turut serta melakukan investasi bagi generasi selanjutnya.

\section{SIMPULAN}

Dari hal hal yang diuraikan peneliti, maka dapat disimpulkan bahwa, Praktik CSR berlandaskan Tri Hita Karana di Puri Santrian Hotel sudah dilakukan baik secara internal maupun eksternal perusahaan. Praktik CSR tidak memberikan dampak secara langsung bagi keuangan Puri Santrian Hotel. Dengan melakukan implementasi CSR meningkatkan loyalitas pengunjung terhadap hotel, hal ini merupakan salah satu keuntungan penerapan CSR. Selain meningkatkan loyalitas pengunjung, CSR memiliki dampak positif lainnya berdasarkan triple bottom line adapun dampak dari pelaksanaan CSR dari sisi kemanusiaan yakni meningkatkan kesejahteraan social bagi mereka yang mendapatkan bantuan, dari sisi lingkungan menciptakan lingkungan yang 
nyaman dan bersih, dari sisi keuangan dampak CSR menambah beban perusahaan, namun meningkatkan loyalitas pengunjung.

Adapun kekurangan dalam penelitian ini adalah kurangnya informasi laporan keuangan dan biaya yang dikeluarkan untuk mendanai proses CSR, bagi peneliti selanjutnya dapat menambahkan aspek indicator GRI, serta laporan keuangan perusahaan, agar dapat menambah bukti-bukti penerapan implementasi CSR dan memperdalam pertanyaan-pertanyaan yang diberikan.

\section{REFERENSI}

Ahmed, A. H. (2017). Corporate Social Responsibility (CSR): A Conceptual and Theoretical Shift. 7(1), 203-212. https://doi.org/10.6007/IJARAFMS/v7i1/ 2626

Amaluddin, L. O. (2018). Impact Of Policy Implementation Corporate Social Responsibility ( Csr ) At Pt. Aneka Bangunan Cipta In Amoito Jaya Village, Subdistrict Of Wolasi, District Of South Konawe. 6(6), 259-268. https://doi.org/10.890/DOSK/d23/2626

Apriyanti, N., \& Budiasih, I. (2016). Profitabilitas dan Corporate Social Responsibility Pada Perusahaan High dan Low Profile. E-Jurnal Akuntansi, 14(2), 977-1004. https:// doi.org/10.776/EJA.il-ey5465

Bangun, et al., (2019). Pengaruh Pengungkapan Corporate Social Responsibility Terhadap Kinerja Keuangan Perusahaan ( Studi Empiris pada Perusahaan yang Terdaftar di Indeks SRI-KEHATI Bursa Efek Indonesia ). VI(1), 127134. https:// doi.org/10.990/k-234-i / 27413

Fordham, A. E., \& Robinson, G. M. (2018). Mapping meanings of corporate social responsibility - an Australian case study. International Journal of Corporate Social Responsibility, 3(1), 1-20. https:/ / doi.org/10.1186/s40991-018-0036-1

Garcia-Chiang, A. (2018). CSR in the Mexican oil industry: Social impact assessment as a tool for local development. International Journal of Corporate Social Responsibility, 3(1). https:/ / doi.org/10.1186/s40991-018-0038-z

Hategan et al., (2018). Doing well or doing good: The relationship between corporate social responsibility and profit in Romanian companies. Sustainability (Switzerland), 10(4). https:/ / doi.org/10.3390/su10041041

Helming, et al., (2016). Under Positive Pressure: How Stakeholder Pressure Affects Corporate Social Responsibility Implementation. 55, 1-36. https://doi.org/10.1278/y -334il

Koolwal, N., \& Khandelwal, S. (2019). Corporate Social Responsibility ( CSR ) implementation in Oil \& Gas Industry: Challenges and Solutions. 1-11. https://doi.org/10.890/DOSK/d23/2626

Mitra, N., \& Gupta, A. Das. (2018). Communicating Corporate Social Responsibility in the post mandate period: Evidence from India. International Journal of Corporate Social Responsibility, 3(1), 1-16. https:// doi.org/10.1186/s40991-018-0033-4

Moskolaï, D. D. (2016). ScienceDirect Review article The influence of the implementation of CSR on business strategy: An empirical approach based on Cameroonian enterprises. Arab Economic and Business Journal, 11(2), 162171. https:// doi.org/10.1016/j.aebj.2016.04.001 
Nicolaides, B. A. (2018). Corporate Social Responsibility as an Ethical Imperative. 4(4), 285-300. https:// doi.org/10.2345/b-b-tr /yns6

Panungkelan, et al., (2018). Analisis Pengaruh Strategi Green Marketing Dan Corporate Social Responsibility Terhadap Keputusan Menginap Di Hotel Swiss Bell Maleosan Manado. Journal of Strategy Marketing, 6(3), 11781187.https://doi.org/10.890/EMBA /134-89

Pattisahusiwa, S., \& Diyanti, F. (2017). Pengungkapan Corporate Social Responsibility, Struktur Corporate Governance dan Nilai Perusahaan. Jurnal Ekonomi Modernisasi, 25. https://doi.org/10.21067/jem.v13i1.1763

Pertiwi, I. D. \& Ludigdo, U. (2019). Implementasi Corporate Social Responsibility. PUSAKA (Journal of Tourism, Hospitality, Travel and Business Event), 1(1), 29-35. https:/ / doi.org/10.33649/pusaka.v1i1.10

Pramana , I. G. A., \& Yadnyana, I. K. (2016). Pengaruh Corporate Social Responsibility Pada Kinerja Perusahaan Manufaktur. E-Jurnal Akuntansi Universitas Udayana16,1965-1988.https:/ / doi.org/10. 6495/EJA.s-1i1.10

Prastuti , N. K., \& Budiasih, I. (2015). Pengaruh Good Corporate Governance Pada Nilai Perusahaan Dengan Moderasi Corporate Social Responsibility EJurnal Akuntansi Universitas Udayana., 13(1), 114-129. https://doi.org/10.8969/EJA.d45.e4

Prutina, Ž. (2016). Effect of corporate social responsibility on organizational commitment. Management (Croatia), 227-248. https://doi.org/10.33649/Su

Rita. (2019). Implementasi Corporate Social Responsibility (Studi Pada Hotel Grand Clarion Makassar). 1(1), 29-35. https://doi.org/10.6712 / d33-et5

Rohman, A., \& Apsari, A. A. (2012). Jpkomunikasidd120168. Perspektif Pelaku Bisnis Perhotelan Di D.I. Yogyakarta Terhadap CSR, 7, 43-54.

Rosilawati, Y., \& Mulawarman, K. (2019). Kearifan Lokal Tri Hita Karana Dalam Program Corporate Social Responsibility. Jurnal ASPIKOM, 3(6), 1215. https://doi.org/10.24329/aspikom.v3i6.426

Rumambi, et al., (2018). Implementation Model of Corporate Social Responsibility (CSR): An Indonesian Perspective. International Journal of Academic Research in Business and Social Sciences, 8(10), 761-773. https://doi.org/10.6007/ijarbss/v8-i10/4777

Sari, et al., (2017). Implementasi Corporate Social Responsibility ( Csr ) Dan Dampaknya Terhadap Kinerja Keuangan Pada Industri Perhotelan ( Studi Kasus Pada Melia Bali Hotel ). 1(1). https:/ / doi.org/10.1093/ije/dym012

Sari, K. C. (2018). Pengaruh Corporate Social Responsibility ( Csr ) Terhadap Kinerja Keuangan Perusahaan ( Studi Pada Sektor Agrikultur yang Terdaftar di Bursa Efek Indonesia Periode 2016- 2018 ). 73(1), 178-186. https://doi.org/10.5005/bssdr/E5-Ir / 4777

Satya, D., \& Hidayatullah, D. S. (2018). Pengaruh Program Corporate Social Responsibility Terhadap Citra Perusahaan ( Studi Pada Pt . Sucofindo Tahun 2017 ). 5(2), 1925-1931. https://doi.org/10.1122/mnt/dyo12

Suciawati, D. . (2016). Pengaruh Corporate Social Responsibility Terhadap Kinerja Keuangan. 12(2), 104-113. https:// doi.org/10.1261/n-ky/dokys1

Uang, H., \& In, W. H. L. (2017). The Current Conditions Of Csr Implementation In Construction Industry: A Lesson From Taiwan. 15(2), 67-80. 
https://doi.org/10.1421/won/deuk41

Umawan, A. A. N. K. P., \& Putri, I. G. A. M. (2017). Analisis Pengungkapan Dan Dampak Penerapan Corporate Social Responsibility Di Hotel the Westin Resort Nusa Dua. E-Jurnal Akuntansi Universitas Udayana, 19(1), $27-$ 50.https://doi.org/10.6142/EJA.O-hty6.wwrt

Vo, L.-C. (2015). Motives Behind The Integration Of CSR Into Business Strategy: 31(5), 1975-1986. https:// doi.org/10.8902/ su-12do-ky1

Wang, et al., (2016). Thematic Issue on Corporate Social Responsibility Corporate Social Responsibility: An Overview And New Research Directions. 59(2), 534-544. https://doi.org/10.2338/V-iju/45-at

Widanaputra, et al., (2017). Reputasi Perusahaan, Reputasi Manajemen Puncak, Dan Corporate Reputation, Top Management Reputation, and Corporate Social Responsibility Disclosure. (2014), 75-84. https://doi.org/10.8935/kilj.yui1.890

Yaputra, H., \& Sudibyo, Y. A. (2019). Persepsi Konsumen Terhadap Kegiatan Csr Dalam Industri Hotel Di Provinsi Bali. Jurnal Manajemen Dan Pemasaran Jasa, 12(1), 35. https:// doi.org/10.25105/jmpj.v12i1.3645 